\title{
Freedom of the Press: Freedom from the Press*
}

\author{
Sir David Calcutt, $Q C$
}

As the Parliamentary Summer Recess once again approaches, it is perhaps appropriate that we should be considering the balance which has yet to be effectively struck between the freedom of the press, and freedom from the press - that is, the freedom of the press to investigate and to inform the public about matters of legitimate public interest; and the freedom of the individual to be protected from public exposure, by the press, of private matters, but in which the public has no legitimate interest.

After all, it is now over five years since the Government called for - and called for as a matter of urgency - a Report on the measures needed (whether legislative or otherwise) to give further protection to individual privacy from the activities of the press.

It is now over four years since the Government accepted, in principle, the recommendations of the Committee on Privacy and Related Matters that a package of changes (including some legislative changes) was needed, and accepted the recommendation that this must positively be "the last chance" for the press to get its act together, failing which statutory support would be inevitable.

It is now over two years since the Government asked me to review - and to review urgently - the new arrangements which the press had put in place for self-regulation, and to say whether, in my view, those arrangements should now be modified or put on a statutory basis.

It is now over 18 months since the Government expressly accepted, in terms, my conclusion that the Press Complaints Commission was not an effective regulator of the press.

It is now over 15 months since the National Heritage Select Committee published its Report recommending statutory support for the voluntary regulation of the press.

It is now over 12 months since the Secretary of State for National Heritage assured Parliament that the Government envisaged a White Paper setting out the Government's final views on press self-regulation, and said that the Government would do its best to ensure that its response to the Select Committee's Report would be published before

* The Child \& Co. Lecture 1994. 
the Summer Recess - by which, I had assumed, he meant the Recess of 1993.

But, to date, no White Paper, still less any Government legislative initiative, has yet been forthcoming.

My purpose in addressing you today is not simply to repeat what the Privacy Committee said in its Report, nor what I said in my Review (though I will summarise it); but rather to take stock of all initiatives, to see where we are - or rather, where we have so far failed to be - and to see where things may go - or may fail to go - from here.

The background is familiar enough. With increased concentrations of media ownership, with decreasing overall newspaper circulation figures, and with coverprice wars becoming increasingly intense, the temptation to go for the simply prurient story, in pursuit of increased sales, often regardless of who may get hurt, becomes increasingly difficult to resist.

Go back five years, if you will, to the 1988-89 Session of Parliament. In that Session there had been widespread support for two Members' Bills, one relating to the protection of privacy, the other to a right of reply. One had been introduced by $\mathrm{Mr}$ John Browne, the other by Mr Tony Worthington. Each Bill had been given a Second Reading. Each had completed its Committee stage in the House of Commons. Neither of these proposals was new. Similar Bills had been introduced in the previous parliamentary session by Mr William Cash, and by Miss Ann Clwyd. And these Bills had themselves each been based on earlier Bills.

Public concern, in 1989 , was temporarily assuaged by the familiar device of setting up a Committee to recommend what should be done.

The Committee's terms of reference are now worth repeating. They were:

"In the light of the recent public concern about intrusion into the private lives of individuals by certain sections of the press, to consider what measures (whether legislative or otherwise) are needed to give further protection to individual privacy from the activities of the press, and to improve recourse against the press for the individual citizen . . ."

Considering, for one moment, those terms of reference, the focus of attention was to be on the press; it did not extend to the whole of the media. This limitation had its advantages; it also had its obvious disadvantages.

Secondly, the Inquiry was to focus particularly on those measures needed to provide adequate protection to an individual's privacy: it was not principally concerned with such other protection as might be needed.

Thirdly, the Government itself expressly contemplated that legislation might be needed.

It was made plain from the outset that the Committee's Report was required urgently. Parliament had been told that it was intended that the Committee should report within one year; and Ministers on several occasions had spoken publicly of the need for a speedy report. 
The Committee received a great deal of evidence. A number of witnesses, particularly those from the press, provided the Committee with detailed analyses of press practice, and of the wide constraints already placed on them. By contrast, a number of people whose privacy had been the subject of intrusion by the press, often in distressing circumstances, sent the Committee detailed dossiers of their experiences.

Many witnesses argued strongly for press freedom to investigate wrong doing. By contrast, many members of the public wrote to us advocating restrictions on the press. These ranged from the outright prohibition of particular activities, to various forms of recompense, and to a variety of punishments for editors and journalists.

The Report of the Committee was completed almost within the year, and published in June 1990. It was unanimous.

The Report recognised the balance which needed to be struck between freedom of expression and an individual's right to privacy. The Committee took the view that freedom of expression was fundamental in a democratic society, but concluded that this could not be at the expense of other important rights, including an individual's right to privacy.

The Committee made a number of recommendations. They were intended to form part of one overall balanced package. The principal parts of that package can be summarised in this way.

First, any new means of redress would need to be carefully targeted, and should not range more widely than was needed to meet existing gaps in protection.

Secondly, any new wide-ranging statutory civil rights, aimed at the protection of infringement of privacy, although practicable, would not then - as part of the balanced package - have been appropriate.

Thirdly, the most blatant forms of physical intrusion - pratices involving "doorstepping", bugging, and the use of long-range cameras - should, subject to appropriate defences, be outlawed.

Fourthly, the existing statutory restrictions on reporting should be strengthened, so as to provide added protection for children and the victims of sexual offences.

Fifthly, the press's own arrangements for voluntary self-regulation should be revised and strengthened by setting up a new Press Complaints Commission (as detailed in the Report), to replace the old Press Council.

Lastly, if the Press failed to demonstrate that non-statutory self-regulation could be made to work effectively, then the new regulatory arrangements would have to be given statutory support; and the form which that support would need to take was spelt out plainly and in considerable detail.

In the light of what has happened, it is important to see what was said, in June 1990, when the Report (Cm. 1102) was published, both by the Government and by the Opposition.

The then Home Secretary (Mr David Waddington, as he then was) said that the Government warmly welcomed the general approach which the Committee had taken on the delicate issue of balancing privacy for the individual against the maintenance of freedom of expression. He said that the Government was attracted by those 
recommendations which offered the possibility of an immediate remedy against the worst excesses of the Press.

He said that this was positively "the last chance" for the industry to establish an effective non-statutory system of regulation. If a non-statutory commission were established, the Government, he said, would review its performance after 18 months of operation, to determine whether a statutory underpinning was required.

If no steps were taken to set up such a commission, the Government, he said, albeit with some regret, would proceed to establish a statutory framework, taking account of the Committee's recommendations.

$\mathrm{Mr}$ Waddington supported this by an article in The Times the following day. He said that he considered the Committee's recommendations offered a genuine opportunity to restore the responsible exercise of press freedom to all our newspapers. But if, after a trial period, they did not, the Government he said, would not flinch from introducing statutory regulation of the press.

This was, then, emphatically to be "the last chance" for the press to put its own house in order. If that failed, the Government had made it perfectly plain that statutory support would be needed. No suggestion was then made that such statutory support would give rise to any constitutional difficulties.

Mr Roy Hattersley, speaking for the Opposition, gave an unqualified welcome to the Report's positive proposals. He drew attention to the Home Secretary's own express belief that newspapers would respond to this one "Last chance"; but he said that he (Mr Hattersley) had his doubts; and that was why the second recommendation - the introduction of statutory regulation by an official body - was absolutely essential if the "year of grace" was ignored and if the press did not mend its ways.

So, the Opposition, too, took the view that this was to be the "Last chance"; and that if it failed, statutory regulation would follow; and, again, no constitutional anxieties were raised.

But, following publication of the Committee's Report, the Government itself has so far failed to initiate any of the recommended measures which required legislation.

The press, did, however, abolish the old Press Council, and set up, in its place, a new Press Complaints Commission. But the new Commission, as set up by the Press, differed significantly from the Commission which the Privacy Committee had had in mind, the details of which had been fully spelt out in the Report. The principal differences were these.

First, the members of the Commission were to be appointed, not by a body which was itself independent of the press (as the Report had recommended), but, in effect, by a body which was the creature of the newspaper industry.

Secondly, the Report had recommended that the Commission should not act as an overtly campaigning body for press freedom; but there were signs that the Commission was once again asserting, as the old Press Council had done, a positive role for the Commission in defending press freedom.

Thirdly, the Commission operated a Code of Practice produced and monitored, not by the Commission (as the Report had recommended), but by the industry. 
Fourthly, the industry's Code of Practice reduced, in several significant respects, the protection which the Privacy Committee had proposed for individuals: it failed to hold the balance fairly between the industry and the individual.

Fifthly, the industry's Code of Practice widened the concept of "Public interest", thereby significantly reducing the level of protection which ought to have been provided for individuals.

Sixthly, the Commission was generally unwilling to operate a "Hot-line" to prevent anticipated breaches of the Code, as the old Press Council had proposed, and as the Committee had recommended.

Finally, the Commission was then unwilling itself to initiate inquiries, as the old Press Council had done and as the Committee had also recommended.

The new Commission began work on 1 January 1991. This meant that the 18-month period - the time when the Government had promised a review of the Commission's performance to determine whether statutory underpinning was required - expired in July 1992.

It so happened that the end of this 18-month period coincided with the serialisation in the press of Andrew Morton's book, Diana: Her Own True Story and this itself gave rise to a good deal of further public concern about the behaviour of the press.

The Government invited me to undertake the Review of the performance of the Press Complaints Commission. My Terms of Reference are again worth repeating. They were:

"To assess the effectiveness of non-statutory self-regulation by the press since the establishment of the Press Complaints Commission and to give my views on whether the present arrangements for self-regulation should now be modified or put on a statutory basis; and to consider whether any further measures might be needed with intrusions into personal privacy by the press."

The thrust of the Review was thus different from that of the earlier Report. The thrust of the Report had been to consider what measures were necessary to give further protection to individual privacy. The thrust of the Review was to assess the effectiveness of the new self-regulatory arrangements.

The terms of reference of the Review plainly contemplated the possibility that the voluntary arrangements might need to be put on a statutory basis.

There was no suggestion that, if a statutory basis were needed, any constitutional difficulties would be likely to arise.

It seemed to me that, in conducting the Review, I was entitled to take, as my starting point, the Report of the Privacy Committee (including the recommended statutory support which would be needed if the proposed new self-regulatory arrangements proved to be ineffective). After all, that Report, as I have already pointed out, had been unanimous; it had been accepted, in principle, both by the Government and by the Opposition; and the Government was well aware of my views about the fall- 
back statutory support which would be needed, and yet had chosen to come back to me to undertake the Review.

I do not trouble you with the detail of the review. The main conclusions which I reached, on the effectiveness of press self-regulation, were these.

First, the new Press Complaints Commission was not an effective regulator of the Press.

Secondly, it had not been set up in a way, and was not operating a Code of Practice, which enabled it to command not only press - but also public - confidence.

Thirdly, it did not, in my view, hold the balance fairly between the press and the individual.

Fourthly, it was not, in my view, the truly independent body which it should have been.

Finally, as constituted, it was, in essence, a body set up by the industry, and operating a Code of Practice devised by the industry and which was over-favourable to the industry.

It was with regret that I had to reach these conclusions, and, having considered (and rejected) the possibility of modification, I recommended that the Government should put press regulation on the statutory basis detailed in the Report of the Privacy Committee.

I also recommended that the criminal offences relating to physical intrusion and covert surveillance, which had been proposed by the Privacy Committee, should be enacted. I also recommended that the Government should give further consideration to the introduction of a new tort of infringement of privacy.

On 14 January 1993 the Government published my Review. The Secretary of State for National Heritage (Mr Peter Brooke) said in Parliament that the Government accepted the case I had made for new criminal offences to deal with specified types of physical intrusion and covert surveillance; but the case I made was essentially no different in this respect from the recommendations which the Committee had made some 18 months earlier, but which the Government had thus far disregarded.

The Government also accepted my recommendations that further consideration should be given to introduction of a new tort of infringement of privacy.

More significantly, the Government also agreed with me that the Press Complaints Commission, as then constituted, was not an effective regulator of the Press, that it was not truly independent, and that its procedures were deficient.

My recommendation that the Government should not put press regulation on a statutory basis raised, so $\mathrm{Mr}$ Brooke said, separate and more difficult issues which needed to be carefully weighed. The Government, he said, was conscious that action to make such a body statutory would be a step of some constitutional significance, departing from the traditional approach to press regulation in the United Kingdom; and that in the light of those considerations, the Government, he said, would be extremely reluctant to pursue that route. That reasoning, I have to say, and in the light of what had gone before, and which I have just outlined, struck me as curious. Why should such statutory support be so significant a constitutional step that the 
Government should be reluctant to introduce it? Neither Mr Waddington nor $\mathrm{Mr}$ Hattersley appeared to have taken that view in 1990.

The answer must surely depend on the likely effect of the proposed statutory support. If, of course, the likely effect would be to result in censorship and gagging of the press, and to prevent responsible investigative journalism so as to shield the wicked from exposure, that would indeed be a step of some constitutional significance. But if the change simply makes effective, by providing adequate sanctions, that which is presently ineffective, where is the "significant constitutional step"? And what is its vice?

If the concept of press regulation is accepted by the press, as it surely must be (the press having set up the Press Complaints Commission), then it must surely follow that it is effective regulation that is accepted. Or is the press only prepared to accept press regulations so long as that regulation is ineffective? That would be a cynical view indeed. But, as the editor of one of our broadsheets once put it: "The people who own and run our popular press are driven by commercial imperatives that brook no interference."

The statutory support which the Privacy Committee proposed in the event of the failure of the Press Complaints Commission (and which I recommended in my Review) was designed to make, and would have the likely effect of making, a positive contribution to the development of the highest standards of journalism. It would have enabled the press to operate freely and responsibly. It would have given it the backing which was needed, in a fiercely competitive market, to resist the wildest excesses.

The Committee's recommendations were designed to ensure, and would have the likely effect of ensuring, that privacy, which all agreed should be respected, was protected from unjustifiable intrusion, and protected by a body in which the public - as well as the press - had confidence.

So much, then, for a summary of the position of the Report of the Committee and of my Review.

My Review was, in fact, only one of several initiatives which were then being undertaken in respect of the press. I should now say something of the other initiatives, so that the two Government-sponsored Inquiries can be seen in a wider context.

$\mathrm{Mr}$ Clive Soley introduced a Bill entitled Freedom and Responsibility of the Press. That Bill proposed the establishment of a body, to be known as the Independent Press Authority, which would seek the presentation of news, by papers and periodicals, with due accuracy. The Authority's proposed powers would have included the power to determine questions of factual inaccuracy, and the power to order an editor or publisher to publish a correction in the manner specified.

Mr Soley's Bill was given a Second Reading by a large majority. It had completed its Committee Stage, but it was nevertheless "talked out" at its Report Stage in March 1993, and so effectively became dead. Although Mr Soley's concern and proposals were different from mine, his proposals - like mine - envisaged statutory support in the field of press regulation. He proposed a legally enforceable right to correction, and a statutory complaints authority to enforce that right. 
There was another intiative which was being pursued at the same time. In October 1992 the National Heritage Select Committee had announced that it would conduct an Inquiry into Privacy and Media Intrusion. Its primary concern was to be with the privacy of private citizens, rather than public figures. That Committee took evidence during the Winter of 1992-93. Its Report was published in March 1993.

The Select Committee expressly reached the significant conclusion (which I had also reached) that the Press Complaints Commission, as then constituted, was not an effective regulator of the press. The Committee recommended that a statutory press complaints tribunal should not be established (as I had recommended), but rather that there should be appointed an ombudsman with statutory powers to oversee the regulation of the media. The Committee also recommended that certain types of intrusion should be made "civil offences" and other types criminal offences.

Thus the Select Committee, though differing from me about the means, was also of the view that some form of statutory support was needed if press regulation were to be effective.

It really goes a good deal further than that. Although the Select Committee disagreed with my proposals and did so with some theatrical display, the Committee's proposals do not differ very much, in their effect, from mine. A voluntary Press Commission, which has the support of a statutory ombudsman vested with statutory powers and sanctions, is a very different creature from a voluntary Commission which has no such statutory support. And a Commission, so supported, is not essentially different, in its effect, from a statutory Complaints Tribunal.

The Select Committee's proposals, if anything, went further than mine. The conduct caught by their proposed criminal offences would have been wider; and the Committee recommended the introduction of "civil offences".

On 10 June 1993 the Report of the Select Committee was debated in the House of Commons. The Secetary of State for National Heritage said that Governments should normally seek to respond to Select Committee Reports within 2 months, and that he regretted that it had not been possible to do so on this occasion. He said that the political range and importance of the Committee's recommendations made a response within the normal time-table impossible. But he assured the House that the Government would do its best to ensure that its response was published before the Summer Recess. But, as I have already indicated, the 1993 Summer Recess came, and went, without any response having been made.

There has been a further initiative which I should also mention. At the end of July 1993, the Lord Chancellor's Department in response to my recommendations, published a Consultation Paper which sought views on a possible new civil remedy for Infringement of Privacy. Perhaps we may look, for one moment, at what had been going on in the courts and elsewhere.

In Kaye v. Robertson and another ([1991] F.S.R.62; The Times, 21 March 1990) - the case of the well-known actor who was photographed and interviewed in his hospital bed - the Court of Appeal, though granting relief on the ground of malicious falsehood, denied any right at common law for the protection of individual privacy. 
Leggatt, L.J., said this:

"We do not need a First Amendment to preserve the freedom of the press, but the abuse of that freedom can be ensured only by the enforcement of a right to privacy. This right has so long been disregarded here that it can be recognised now only by the legislature. Especially since there is available in the United States a wealth of experience of the enforcement of this right both at common law and also under statute, it is to be hoped that the making good of this single shortcoming in our law will not be long delayed."

In the later case concerning the photographs of the Duchess of York, with $\mathrm{Mr}$ John Bryan, in August 1992, Latham J. had refused an injunction to prevent publication of the photographs, on the ground that English law did not (as was well-known) protect personal privacy.

Lord Lester of Herne Hill (House of Lords, 24 May 1994) has said that the courts are still capable of developing common law remedies for wrongful infringement of privacy, and that they should be allowed to do so. But, as against that, it has been pointed out in the Consultation Paper that, even if this were possible, development by common law is uncertain both as to timing and as to content; and that it should be for Parliament to legislate on privacy, and not for the courts to create a new right.

In launching the Consultation Paper, the Lord Chancellor said this:

"The time has come to ensure that the law protects the privacy of everyone. This is a matter which has been the subject of cross-party study for many years, and I think it right to offer concrete proposals for reform. The way ahead now is to provide a new remedy for individuals, with appropriate defences."

The Lord Chancellor's Consultation Paper suggested, in particular, five things. First, that the right of privacy should now be recognised in law; secondly, that the existing law offered only limited protection for privacy; thirdly, that there should be a new civil remedy, allowing an individual to take a case to court if the infringement caused substantial distress; fourthly, that privacy should cover a person's health, personal communications and family and personal relationships; and finally, that the defences of consent, lawful authority, absolute or qualified privilege and public interest defence should, at the least, be available.

But the Consultation Paper makes it plain that legal aid would not be made available; although "conditional fee arrangements" have been canvassed as a possible alternative, this must be a significant shortcoming.

But, for my present purposes, it is again worth noting that the proposals made in the Consultation Paper again envisaged a form of statutory support for at least part of the ground covered by press regulation.

In the result, those outside the press who have recently had to consider this difficult problem in any depth have all reached the conclusion that self-regulation, without more is not enough, and that some form of statutory support is needed. 
Meanwhile, the Press Complaints Commission has, since January 1993, itself pursued a number of initiatives. I should mention those which strike me as being the most significant.

On 24 February 1993, it was reported in The Guardian that the Commission expected to agree new measures designed to speed up the handling of complaints, and that an increase in the Commission's budget was also likely to be agreed.

In May 1993, the Commission announced a series of measures designed to reinforce public confidence in the authority of the Commission. Membership of the Commission and of its Appointments Commission would be altered so as to meet a perceived misconception regarding the Commission's independence. And the Commission not the industry - would take final responsibility for the Code of Practice.

In June 1993, the Committee launched a new "Help-Line" service. Its stated purpose was to assist members of the public who were concerned that the Code of Practice was likely to be breached in a press investigation relating to them. But the service aimed to provide no more than information about the publication of the news agency involved. It was a pale thing compared with the "Hot Line" which had been proposed by the old Press Council, and recommended by the Privacy Committee.

In July 1993, the industry's Code of Practice was revised in a number of respects. First, explicit responsibility was placed on editors for the actions of their journalists. Secondly, specific provision was made about the use of long-lens photography to take pictures of people on private property. Thirdly, the appropriate manner of reporting of cases involving a sexual offence against a child was expanded and spelt out. Finally, "Public interest" exceptions were given definition, and so narrowed.

In September 1993 the Commission made the anticipated changes in its membership. In addition to the independent Chairman, the Commission, as newly constituted, was to comprise eight non-press members and seven editors.

In January 1994, after the episode concerning the photographs of the Princess of Wales in the gym, the Commission appointed one of its lay members, Professor Pinker, to act as the Privacy Commissioner, giving him powers to investigate urgent complaints about privacy, and to bring those complaints to the Commission for decision under the Code of Practice.

Plainly the Code has now been strengthened, and now comes closer to the recommendation of the Privacy Committee. But why, one may ask, was this not done in the first place? And, even so, has enough been done? And can the industry now deliver effective regulation? Even the present arrangements fall short of the recommendations of the Privacy Committee.

Where stands the press itself in all of this? In matters affecting press regulation, the press tends to speak with one voice. In whatever way the press may present it, self-regulation appears to be the limit to which the press itself is prepared to go; and initiatives suggested by others which contemplate a modest degree of statutory support receive a uniformly hostile press reception, often bordering on paranoia. The press, as the messenger, is not usually at its most detached and objective when it comes to reporting stories critical of the press and of its own statutory arrangements. 
The fragility of the present arrangements was dramatically highlighted by the events surrounding the publication, in November 1993, by the Sunday Mirror (and then by the Daily Mirror) of the photographs taken of the Princess of Wales in the gym.

So far as the Sunday photographs were concerned, the Chairman of the Press Complaints commission condemned - on the Sunday - their publication, as a breach of the industry's Code of Practice, and said that he expected the Mirror Group of Newsapers to avoid any further publication of the photographs.

But on the following day - the Monday - the Daily Mirror repeated publication of the gym photographs, and described the Press Complaints Commission as a body which existed "to protect the liars amongst our disreputable rivals".

It was not so much the publication of the Sunday photographs that was significant, but rather the contempt shown for the Commission on the following day.

Peace, at least outwardly, was restored later that week, but only after an apology had been made by the Mirror Group, and, more remarkably, after the Chairman of the Commission had withdrawn remarks made by him.

If that is the way in which a significant player is prepared to treat publicly its own regulatory body, what hope is there for effective self-regulation? As the Secretary of State was reported to have said at the time, the Press Complaints Commission must make a "quantum leap" if self-regulation was to survive.

Finally, and more importantly, where now stands the Government in all of this? I have so far taken the Parliamentary story up to the debate which took place in June 1993.

During the Autumn of 1993 there were many reports of impending Government activity, but, again, nothing happened. And the Criminal Justice and Public Order Bill contained no relevant clauses.

In February 1994, it was reported in The Independent (14 February) that a comprehensive White Paper on press regulation would be published in March, but that Ministers had yet to agree on introducing a new civil law of privacy. It was said, however, that the Cabinet Committee on Home Affairs had given clearance to the Secretary of State to proceed with his long-awaited White Paper on the Press.

One of the more entertaining episodes in the press's campaign to maintain selfregulation, was the production, in February 1994, by the combined efforts of the Association of British Editors, the Guild of Editors, and the International Press Institute, of a paper called Media Freedom and Media Regulation. Produced, no doubt, in the expectation that the Government was indeed about to produce its long-awaited White Paper, the press, by describing its paper as "an Alternative White Paper', at least demonstrated that the press assumed that the Government was unlikely to propose what the press itself would have wished. As it is, we now have an "Alternative White Paper", but no original "White Paper".

In March 1994 it was reported in the press (The Times, 12 March) that the Prime Minister had ordered a re-think on long-awaited Government plans to tighten regulation of the press, and that a White Paper, due to be published in March, had been torn up amid signs that the effort to lessen press intrusion had run into serious difficulties. 
In April 1994 it was reported (The Daily Telegraph, 9 April) that the Prime Minister had intervened to give the press "One last chance" to introduce effective self-regulation over invasions of privacy. The report was in these terms. "After months of wrangling in Whitehall over the content of a Government White Paper on privacy, Mr Major has decided that there should be a final review period in which newspapers can demonstrate a willingness to make self-regulation work. However, later this Spring, Ministers still intend to publish a long-awaited privacy White Paper containing proposals for legislation. A draft Privacy Bill, accompanying it, is intended to act as a "Sword of Damocles" hanging over the media. Mr Major has decided to hold the Bill in reserve - to be introduced only if it becomes evident that the media have spurned the final opportunity to address growing concern over gross invasions of privacy."

No-one would suggest that the issues involved are anything other than complex - which is presumably one reason, at least, why the Government set up an Inquiry in the first place. No-one can quarrel with a desire, on the part of the Government, to get it right. But, assuming the report is accurate, "a final review period", "a final opportunity", and another "one last chance" all sound distinctly ominous: we have been there before.

But why should there be such inordinate delay? There may sometimes be good sense in some delay; but undue delay may raise wider questions about political will and determination.

As Mr Gerald Kaufman, who was the Chairman of the National Heritage Select Committee, said at the end of the debate in Pariament on 10 June 1993 "If no action is taken, the press will slide backwards in the belief that it has got through its crisis and that it is now all clear for it to return to some of the deeply objectionable ways from which, we hope, it is beginning to emerge."

But that was now said over a year ago. It is for this reason that it now becomes important to consider the Government response made in a debate in the House of Lords in May.

On 24 May, Lord Ackner, in Committee, moved an amendment to the Criminal Justice and Public Order Bill to insert a new clause directed to breaches of privacy with intent to obtain and publish information (as proposed by the Privacy Committee).

Earl Ferrers, speaking on behalf of the Government, said this.

"There is now doubt that the behaviour of certain sections of the press, intruding into personal lives of both celebrities and ordinary members of the public, has, on occasion, been nothing less than deplorable . . When any suggestion is made that there should be legislation to curtail such activities, there is a pathetic cry of 'Don't touch the press'. If there is to be freedom of the press - and there should be - it is a privilege which carries a two-way responsibility.

In any proposal for legislation which attempts to balance two rights, there are inevitably problems of principle and of definition which have to be resolved. It is essential that any proposals in this field should find the right balance between, 
on the one hand, the application of criminal and civil law, and, on the other hand, the freedom of the press and the rights of others, notably the right to privacy.

Any legal formulation in this difficult and sensitive area must be defined as clearly and unambiguously as possible if we are to ensure that it catches unacceptable intrusions but that it allows legitimate investigative work to continue.

I shall not conceal from the Committee that we have found it very difficult to reconcile those conflicting claims and to ensure the necessary precision in any legislative proposal.

The various efforts which have been made in the past to control the excesses of the press behaviour are only too well known.

The Committee is aware of how much time has passed and the fact that the Government have not yet made up their mind on these important questions. But I can assure the Committee that the Government have not been idle.

It has become plain to us that the issues involved are very complex and sensitive, but they need to be considered as a whole in order to ensure that the balance is properly struck."

So far, then, so good. But there then followed an indication that the whole matter would one day - but not yet - be thrown back into the public arena. The Minister said this.

"With an issue of such importance, it is essential that we get things right and that any proposal should be the subject of fully informed and national consideration ... We propose to issue a White Paper on the whole subject of press intrusion into privacy. In addition to dealing with the questions of self-regulation and a new civil tort, the White Paper will also consider in some detail the various questions, both of practice and of principle, to which any extension of the criminal law in this area would give rise. This will give Parliament and the public an opportunity for us to take a wider and fuller view."

The Minister had given no indication when the White Paper would be published. Lord Ackner asked for this information; but the response was not encouraging.

The Minister said that the White Paper would be produced when it was ready, but that it was unlikely to be immediate, because the Government had yet to make up its mind. But if the Government does not make up its mind, what will happen?

Lord Renton enquired about the true nature of the Government's intended paper. Was it truly to be a White Paper (as the Minister had described it), which, as Lord Renton put it, was "rather conclusive and usually a prelude to legislation"? Or was it, in truth, what is commonly spoken of as a "Green Paper" - i.e. a consultative paper?

The Minister replied in these terms.

"It is clear to say my noble friend Lord Renton and the Committee that the Government have not yet made up their mind and are considering the position. the object of a White Paper is to enable the Government to say 'There are our 
thoughts', and find out what is the reaction of the public. That will be the purpose of the White Paper."

In saying this, the Minister was simply confirming what he had said earlier. But if the Government's purpose is to engage in national and public consideration, in what are acknowledged to be very complex and sensitive issues, was there any real point in setting up the Privacy Committee in the first place? And who is likely to guide national and public consideration, if it be not the press? But if there is to be such consideration, why should there also be the delay?

The real issue, I suspect, may be a very different one. It is this. Does the Government really have the political will and dertemination to do what it judges needs to be done? Further delay, followed - one day - by a paper which perhaps offers another "last chance", and which invites public consideration, followed possibly by yet another "Last chance", may only serve to foster at least the thought that, notwithstanding all the recommendations which have been made, there is, in fact, no political will to do anything about it at all.

As the 1994 Summer Recess approaches, with still no Government repsonse, so too - and perhaps you may say "thankfully" - does the Long Vacation; and I leave all these thoughts to you for your peaceful vacation contemplation. 